\title{
Assessment of the regional water balance of the limestone subaquifers of Cyprus
}

\author{
Aldalou Ahmed A JAmal ${ }^{1}$ and Umut Türker ${ }^{2, *}$ \\ ${ }^{1}$ Civil Engineering Department, Division of Hydraulics, Near East University, Nicosia, North Cyprus, Turkey. \\ ${ }^{2}$ Division of Hydraulics, Civil Engineering Department, Eastern Mediterranean University, 99450 Famagusta, \\ North Cyprus, Turkey. \\ ${ }^{*}$ Corresponding author.e-mail: umut.turker@emu.edu.tr
}

The northern part of Cyprus is usually characterized by its small watersheds and the lack of ephemeral surface water resources. Therefore, all the water dependent activities depend on groundwater resources. Kyrenia Range subaquifers are the only natural domestic water supplying sources, fulfilling the required worldwide drinking water quality standards. In the present study, various hydrogeological factors that could influence the aquifer recharge and abstraction are used together with annual groundwater level changes, to estimate the capacity of each subaquifer distributed at the Kyrenia Range randomly. During the analyses, 11 subaquifers are worked out; and their spatial distribution, the depth, and the daily abstraction from the available wells are surveyed. The results show that annual groundwater recharge into the subaquifers is $1126 \mathrm{~mm}$. It is also observed that the subaquifers recharging from the southern foothills are more vulnerable to climate effects than the ones at the northern foothills. The available water storage at the present situation, at each subaquifer, is calculated individually and finally the total storage capacity of Kyrenia Range subaquifers, is assessed as 214 million cubic meters (MCM); whereas the data analyses show that annual abstractions from the 11 subaquifers is 13.34 MCM, annually.

\section{Introduction}

The groundwater resources of northern part of Cyprus are limited, suffering both from droughts as well as mismanagement. In all, $95 \%$ of domestic and agricultural water consumption is maintained from groundwater resources. However, for the last decade, the rate of recharge has decreased below the rate of discharge declining the saturation thickness of most of the aquifers. The inevitable consequences of this were drying out of spring outflows and quality deterioration of groundwater resources. The total catchment area of the northern part of Cyprus is nearly $3300 \mathrm{~km}^{2}$. The total average annual rainfall is estimated to sum up to $1200 \mathrm{ml}$ $\mathrm{m}^{3}$. This gives an average annual rainfall of about
$364 \mathrm{~mm}$. Only a small percentage of precipitated water infiltrates is stored in the aquifers. Hence, it can be made available for future use (Dixey 1972). It is therefore necessary to carry out groundwater resources research studies for the evaluation of the sustainability of the aquifers.

Neglecting the size of the water bearing formations, there are 12 major aquifers distributed around the northern part of Cyprus (Turker et al. 2013). Among these 12 groundwater resources, Kyrenia Range limestone aquifer is the only potable groundwater source available at the region. The first general hydrogeological survey of this aquifer was held in 1951 by David Burdon, who has surveyed, assembled, and summarized all the essential facts about the groundwater resources of

Keywords. Cyprus; evapotranspiration; infiltration; Kyrenia Range; storage capacity; subaquifers. 
Cyprus (Burdon 1952). Later, the report of United Nations Developing Program (UNDP), was the last report written ever, to perform the water resources management study of the whole Cyprus (UNDP 1970). Early detailed studies of Kyrenia Range aquifers were initiated during 1963-1964 period, when the German Technical Assistance Mission examined the principal limestone outcrops of the range, and carried out a considerable drilling program in these rocks (Mixius and Kreysing 1965; Kluyver 1967). Ducloz (1965) has given a valuable list of springs and seepages for the region, showing elevations and minimum and maximum yields. Dixey (1972) performed water balance studies for the Kyrenia Range aquifers, including consideration of spring flows, storage capacity, recharge and other hydrological factors. During the project, 15 boreholes were mounted mainly for specific group of villages, to gain further information on the occurrence and the extent of the groundwater resources of the range. However, today, most of these boreholes have dried, been abandoned or have collapsed due to mismanagement of the available water resources. Lately, Gökmenoğlu et al. (2004) in their research drilled 22 boreholes for monitoring purposes; carried out geophysical studies, and worked out the hydrodynamic structure of the Kyrenia Range aquifers. Some of the boreholes drilled by Gökmenoğlu et al. (2004) are still in use for potable water supply purposes by the water resources authorities. Eventually, Endreny and Gokcekus (2008) worked out the possibilities of draining water resources from Kyrenia Range subaquifers with the help of horizontal qanats. Their main aim was to minimize the energy consumption, while increasing the discharge capacity of subaquifers. After all those studies and surveys on the Kyrenia Range aquifer, governmental authorities in 2004 initiated well monitoring program to gather hydrological and hydrogeological data and information about the aquifer to be used for future studies.

The literature reviews show that Kyrenia Range aquifer was previously considered as a whole limestone body $\left(62 \mathrm{~km}^{2}\right)$, which led to a great uncertainty in the relationship between each well and its link with both hydrological and meteorological parameters. Thus, water budget studies were performed based on well capacities instead of an aquifer capacity. In the course of this study, an attempt has been made to divide the Kyrenia Range aquifer into 11 different subaquifers to assess the relationship between hydrological and meteorological characteristics and head distributions of each subaquifer for investigating the water budget of each subaquifer. Assuming each subaquifer as a whole to be represented as a control volume, the volumetric approach is used for the modeling of the capacity of water resources of each subaquifer.
Therefore, the aim is achieved by the implementation of mass balance model.

\section{The geology and hydrogeology of Kyrenia Range}

The rocks in the Kyrenia Range are generally classified as either allochthonous or autochthonous. The allochthonous blocks forming the core of the Kyrenia Range are collectively called the Hilarion limestones. This limestone zone comprises a number of distinct formations of Triassic, Jurassic and Early or probably Middle Cretaceous age forming Pre-Campanean sediments group. Hilarion, Sykhari and Dhikomo formations belong to this group (Pantazis 1978). The Lapithos group is of Maastrichtian to Eocene age and is divided into three formations as Melounda, Ayios Nikolaous and Lapithos formations. Melounda and Ayios Nikolaous formations belong to allochthonous blocks from Maastrichtian to late Paleocene age, whereas the Lapithos Formation belongs to autochthonous blocks of Eocene age. From oldest to youngest, the younger formations of the autochthonous blocks are the Lapithos Formation, the Kalogrea-Ardana Formation, the Kythrea Group (including the Lapatza Formation), the Kalavasos Formation, and the Nicosia Formation; of these units, Lapithos, Kalogrea-Ardana, and Kythrea are unique to the Kyrenia Range (Harrison et al. 2008). Stratigraphy of the tectonic zones of both allochthonous and autochthonous blocks are given in figure 1 .

The limestone rocks of the Kyrenia Range are heavily fractured outcropping over an area of 62 $\mathrm{km}^{2}$, from Karşıyaka (Vasillia) in the west to Tirmen (Trypimeni) in the east running parallel to the northern coast of Cyprus. It is $45 \mathrm{~km}$ in length and at some locations its summits rise up to $900 \mathrm{~m}$, but in general the average elevation of the range is $600 \mathrm{~m}$. The range forms an effective physical and climatologic barrier between the central plain and the northern coast, creating a contrast on the vegetation cover of the two flanks. The northern slopes are well clothed with pine and cypress forests whilst the southern slopes bear phrygana and maquis scrub down to the semi-arid plains of Mesaoira (Dreghorn 1978). Through karstification, the Mesozoic rocks acquired good water bearing properties which, however, are limited by the fact that during their tectonic history the blocks were separated into several compartments (UNDP 1970). These compartments have different water table elevations varying around 250 and $100 \mathrm{~m}$ above sea level. The recognition of these compartments of the range was first raised by Sir Frank Dixey (1972). This recognition marks a considerable advancement in our knowledge of the hydrogeology of the range. 
KYRENIA RANGE

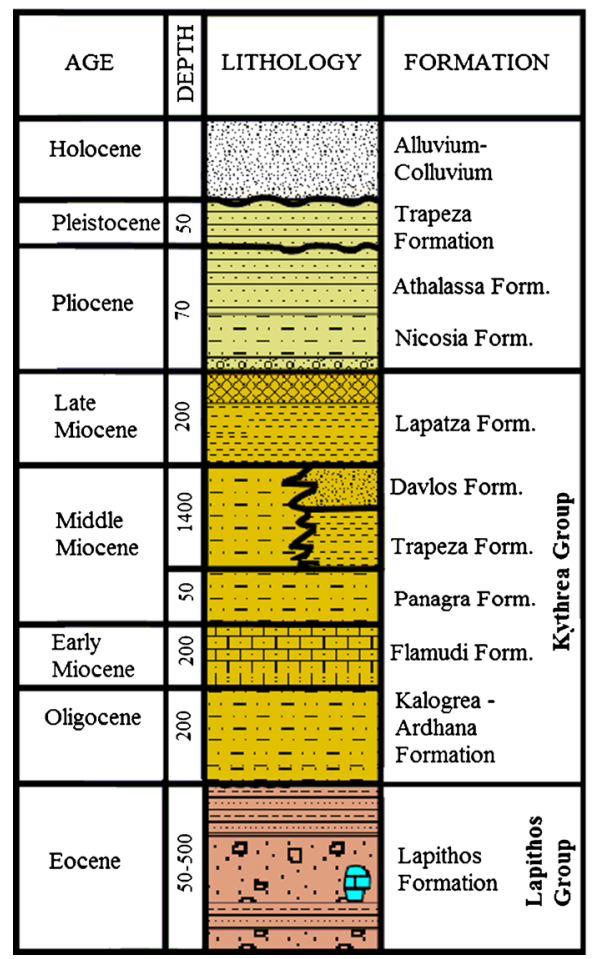

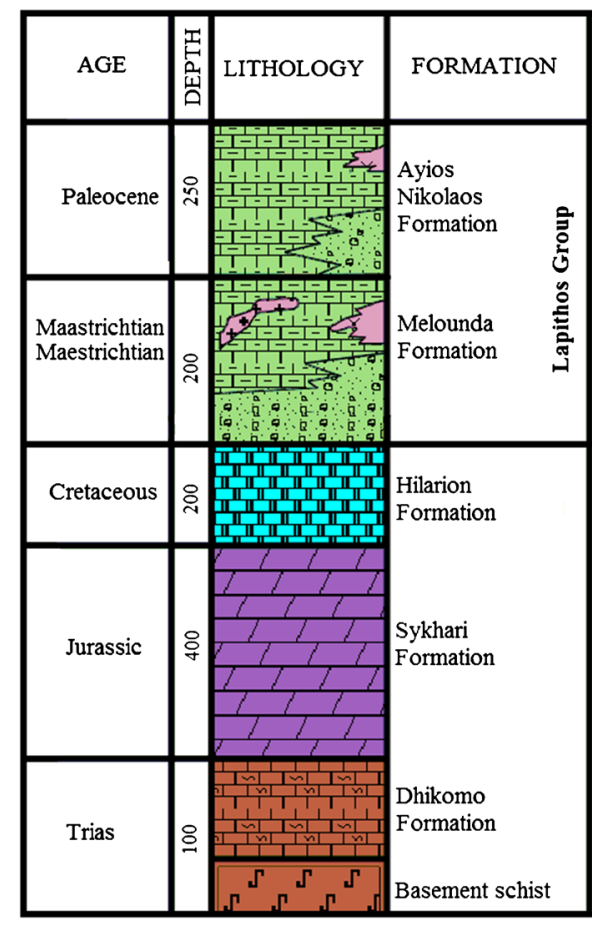

Figure 1. Stratigraphy of the tectonic zones of Kyrenia Range of Cyprus. The stratigraphic columns are not drawn in scale (modified from Erduran et al. 2004).

Table 1. List of 11 subaquifers.

\begin{tabular}{cll}
\hline No. & \multicolumn{1}{c}{ Region name } & $\begin{array}{c}\text { Direction } \\
\text { of foothill }\end{array}$ \\
\hline 1 & Karşıaka (Vasillia) & Northern face \\
2 & Lapta (Lapithos) & Northern face \\
3 & Alsancak (Karavas) & Northern face \\
4 & Karaman (Karmi) & Northern face \\
5 & Dikmen (Dhikomo) & Southern face \\
6 & Çatalköy (Ayios Epiktitios) & Northern face \\
7 & Değirmenlik (Kythrea) & Southern face \\
8 & Alevkayasi(Alevga) & Southern face \\
9 & Tirmen (Trypimeni) & Southern face \\
10 & Kantara (Kantara) & Northern face \\
11 & Boğaz (Boghaz) & Southern face \\
\hline
\end{tabular}

Dixey (1972) conducted a survey on the spring elevations and borehole water levels throughout the range. He has shown that at least four separate aquifer compartments exist within the range. These subaquifers were Lapta (Lapithos), Dikmen (Dhikomo), Alevkayası(Alevga) and Tirmen (Trypimeni). Nowadays, these four subaquifers can be rescheduled and seven more subaquifers can be added to the list after a review on available groundwater resources (table 1 ).

The criteria of dividing the entire aquifer into 11 subaquifers are based on the existence of already operating as well as surrounding dried and abandoned wells. Today, 38 wells are operating at Kyrenia Range and these wells are located at a close proximity within each other at each defined subaquifer system. There have been several new well drilling attempts out of the boundaries of subaquifers which have failed to explore groundwater sources. It was also necessary to note that the water table elevations at each subaquifer were homogenous, while showing differences between the two different subaquifers. Finally, the frequent and irregular occurrence of faults on Kyrenia Range, were the main reasons for dividing the range into several subaquifers. The geologic formation of Kyrenia Range subaquifers allows the spring discharges in which more than 30 naturally flowing springs were active. These springs were used to discharge 0.5-4 million cubic meters annually. However, the extensive over-pumping during the last 25 years dramatically depleted the water levels. As a result, most of the springs dried up. The crosssectional view of the Alevkayasıand Değirmenlik subaquifer regions is given in figure 2 .

\section{Water balance model for limestone subaquifers}

A successful groundwater management study is required to preserve the sustainability of groundwater resources at Kyrenia Range subaquifers. 

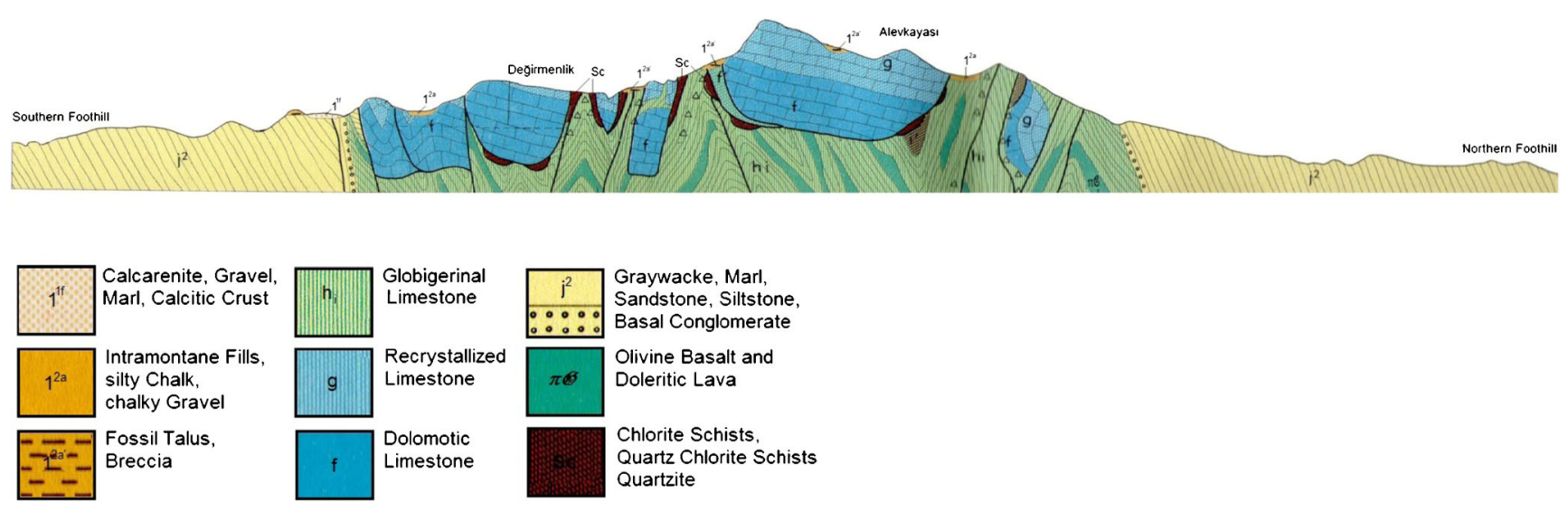

Figure 2. Cross-section of Kyrenia Range along Alevkayası and Dikmen (modified from Ducloz 1972).

According to the theory of conservation of mass, the difference between the net water inflow and outflow from each aquifer results in net change of volume of water per unit time. The general water balance equation for each subaquifer at any time interval can be expressed as:

$$
Q_{\text {net }}=Q_{\text {in }}-Q_{\text {out }}
$$

where $Q_{\text {net }}$ is the change in groundwater storage defined as negative when the groundwater overexploitation is dominant and positive when the rate of abstraction is less than the rate of recharge. $Q_{\text {in }}$ is the total volume of inflow representing recharge from precipitation and $Q_{\text {out }}$ is the total volume of outflow including abstraction for domestic use and spring outflow. On the other hand, the change in groundwater storage is the rate of change of storage volume with respect to time.

$$
Q_{\text {net }}=\frac{\Delta \forall}{\Delta t}=\frac{\Delta h}{\Delta t} \times A
$$

$\Delta \forall$ is the change in the volume of storage, $\Delta t$ represents the change in time and, $\Delta h$ is the change in head while $A$ represents the surface area of groundwater resources. Inserting equation (2) into equation (1) results as:

$$
\frac{\Delta h}{\Delta t} \times A=Q_{\text {in }}-Q_{\text {out }} .
$$

Dividing both sides of equation (3) into the surface area of groundwater will result as:

$$
\frac{\Delta h}{\Delta t}=\frac{Q_{\text {in }}-Q_{\text {out }}}{A} .
$$

There are many small ephemeral streams draining over the foothills of the Kyrenia Range. Usually these rivers experience flash flows during storms, minimizing the infiltration rates. On the other hand, series of high plains, which are either partially or completely enclosed, is spread out along the Kyrenia Range. The floors of the plains are relatively smooth and flat, slightly tilting in the east-west direction, forming a flat landscape. Most of these plains appear to have no exit channel, increasing the infiltration and evaporation with negligible surface runoff. Therefore, except evapotranspiration, the precipitation generally recharges the subaquifers. In contrast, due to high temperature the mean daily evapotranspiration is generally higher than the precipitation except in winter months. Therefore, the difference between the precipitation and evapotranspiration per month yields infiltration capacity of the subaquifers, which can also be considered as the inflow to the subaquifers.

$$
\left(I_{\text {inf }}\right)_{\text {month }}=\left(I_{\mathrm{ppt}}\right)_{\mathrm{month}}-\left(O_{\mathrm{evp}}\right)_{\mathrm{month}}
$$

in which $I_{\text {inf }}$ is the monthly infiltration per month (in $\mathrm{mm}$ ); $I_{\mathrm{ppt}}$ is the monthly precipitation (in $\mathrm{mm}$ ) and $O_{\text {evp }}$ is the monthly evapotranspiration from the basin area. Since infiltration is the only inflow, $Q_{\text {in }}$ can be written as:

$$
Q_{\text {in }}=I_{\text {inf }} \times A_{d} .
$$

Adding that $A_{d}$ is the drainage area of each subaquifers, the continuity equation results in

$$
\frac{\Delta h}{\Delta t}=\frac{\left(I_{\mathrm{inf}} \times A_{d}\right)}{A}-\frac{Q_{\mathrm{out}}}{A} .
$$

Equation (7) is derived based on the fact that the Kyrenia Range subaquifers are following a homogenous and isotropic property and can be further simplified with the assumption of drainage area being equivalent to the ground surface area of the groundwater resources. This assumption works well when referring back to the recharge terraces of the limestone aquifers and the sharp limestone bursting out from the clay surfaces and flat drainage 
areas in the region. The resultant relationship is developed into equation (8)

$$
\frac{\Delta h}{\Delta t}=I_{\mathrm{inf}}-\frac{Q_{\mathrm{out}}}{A}
$$

The long term changes in the areal distribution of groundwater resources and spring flow show that as the radial distance from a predefined central point increases, the groundwater level decreases and the springs dry up. Also, the cross-sectional view of Değirmenlik and Alevkayası subaquifers (figure 2) clearly shows that it can be accepted that the groundwater is stored in subaquifers, which are like part of a sphere, called frustum of a sphere (figure 3). The assumption motivates the groundwater storage capacity analysis to be followed using the frustum of a sphere. The volume of water available in each subaquifer can then be calculated by the help of the volume definition of frustum of a sphere as follows:

$$
V=\frac{1}{3} \pi h^{2}(3 r-h)
$$

where $h$ is the height of water from the deepest point of the frustum of the sphere and $r$ is the radius of the spherical shape. Rewriting equation (8) in terms of radius of drainage area and inserting into equation (9) gives final relationship for volume of water available at each subaquifer of Kyrenia Range.

$$
V=\pi h^{2}\left(\sqrt{\frac{Q_{\mathrm{out}}}{\pi\left(I_{\mathrm{inf}}-(\Delta h / \Delta t)\right)}}-\frac{1}{3} h\right) .
$$

From the various hydrogeological parameters and by the help of equation (10) so far, it can be possible to make a tentative water balance for the subaquifers of the Kyrenia Range.

\section{Results}

\subsection{Evapotranspiration and rainfall estimates}

Evapotranspiration is the most significant water loss from the catchments of the region. Dense, uniform vegetal cover minimizes the evaporation values, relative to the other parts of Cyprus, but increases the significance of evapotranspiration. Depending on the type of vegetal cover, evapotranspiration values at the region vary in space and time. The Penman-Monteith method is used to measure evapotranspiration at each subaquifer region. The method calculates evapotranspiration $\left(E T_{0}\right)$ based on the following equation.

$E T_{0}=\frac{0.408 \Delta\left(R_{n}-G\right)+\gamma(900 /(T+273)) U_{2}\left(e_{s}-e_{a}\right)}{\Delta+\gamma\left(1+0.34 U_{2}\right)}$

where $E T_{0}$ is the reference evapotranspiration (mm/day), $R_{n}$ is the net radiation at the crop surface $\left(\mathrm{MJ} / \mathrm{m}^{2}\right.$ day), $G$ is the soil heat flux density $\left(\mathrm{MJ} / \mathrm{m}^{2}\right.$ day), $T$ is the mean daily air temperature at $2-\mathrm{m}$ height $\left({ }^{\circ} \mathrm{C}\right), U_{2}$ is the wind speed at $2-\mathrm{m}$ height $(\mathrm{m} / \mathrm{sec}), e_{s}$ is the saturation vapour pressure $(\mathrm{kPa}), e_{a}$ is the actual vapour pressure $(\mathrm{kPa})$, $\Delta$ is the slope vapour pressure curve $\left(\mathrm{kPa} /{ }^{\circ} \mathrm{C}\right)$, and $\gamma$ is the psychometric constant $\left(\mathrm{kPa} /{ }^{\circ} \mathrm{C}\right)$. The climatological data obtained from State Meteorology Department, including rainfall, net radiation, temperature, etc., within and surrounding the subaquifers were gathered from six different meteorological stations. The stations were selected according to their proximity to the catchment areas of subaquifers, reliability, and period of their records (10 years). Initially, double mass curve analysis was performed in order to investigate the homogeneity of the rainfall data from each station. Minor scatter around the mean line, with no definite deviations from the slope of the mean line, approved the consistency of the available data. Later, the

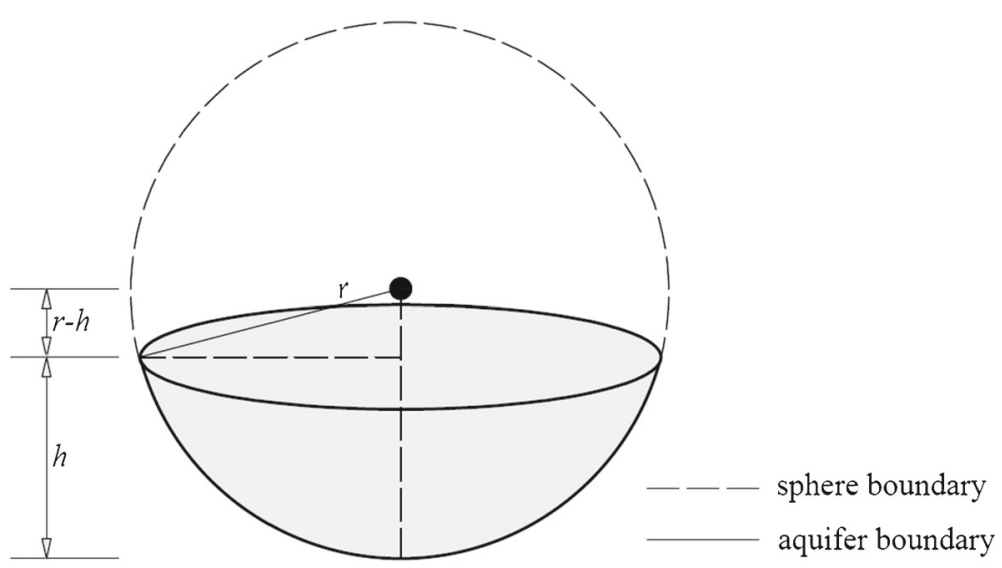

Figure 3. Conceptual representation of subaquifers in the form of frustum of a sphere. 
monthly arithmetic means of 10-year data is calculated and used as the representative rainfall values. Hence, monthly basis rainfall analyses were performed during the study.

Figure 4 shows the 10-year average monthly evapotranspiration and rainfall values of six different meteorological stations.

Evapotranspiration calculated based on the regional climatological observations, gives peak in July at all regions, while the evapotranspiration values at Lapta is highest. Evapotranspiration in summer is $150-200 \mathrm{~mm}$ per month; whereas it decreases to $50-80 \mathrm{~mm}$ at winter months. When the evapotranspiration for each region are compared with the precipitation, it is seen that only during November, December, January, and February regional precipitations exceed evapotranspiration values promoting infiltration at the region.

Based on the climatologic data, 10-year mean annual rainfall of the Kyrenia Range is $462 \mathrm{~mm}$. There are many ephemeral small streams, draining over the range without recharging into the subaquifers. Recharging is mainly due to the infiltration of ponded water at terraces located at upper parts of the range.

The long and narrow Kyrenia Range plays an important part in the meteorology of Cyprus. Temperatures commonly exceed $30^{\circ} \mathrm{C}$ during May, June, July, and August and fall below $4^{\circ} \mathrm{C}$ for a few days during the winter months. Snow rarely occurs upon the upper hills of Kyrenia Range. The maximum snowfall at Kyrenia Range over the last 15 years is recorded as $15 \mathrm{~cm}$.

\subsection{Subaquifer recharging capacity}

The evaluation of groundwater recharge involves several factors of which the rainfall and evapotranspiration are paramount. There are number of techniques available for estimating groundwater recharge, based on physical methods (Obuobie et al. 2012). One of these methods is based on explicit determination of different hydrologic and hydrogeologic components involved in the water balance equations (Liu 2011). When run-off is not significant, groundwater recharge is accepted to be approximately equal to the difference between rainfall and evapotranspiration (Flint et al. 1996). This difference based on monthly rainfall and evapotranspiration difference is used in this study, because its applicability in terms of geological and morphological base of the region is logical. Furthermore, the method is easy to use and requires minimum data since one of the significant water budget estimation variables, spring flow, is almost negligible for the last decade.

On the basis of a computed long term average infiltration of $140 \mathrm{~mm} \pm 20 \%$, the UNDP reports considered the total annual recharge to be 11.5 $\mathrm{MCM} \pm 20 \%$. Dixey (1972), on the basis of major and minor spring outflows considered annual recharging as approximately 10.32 $\mathrm{MCM}$ and long

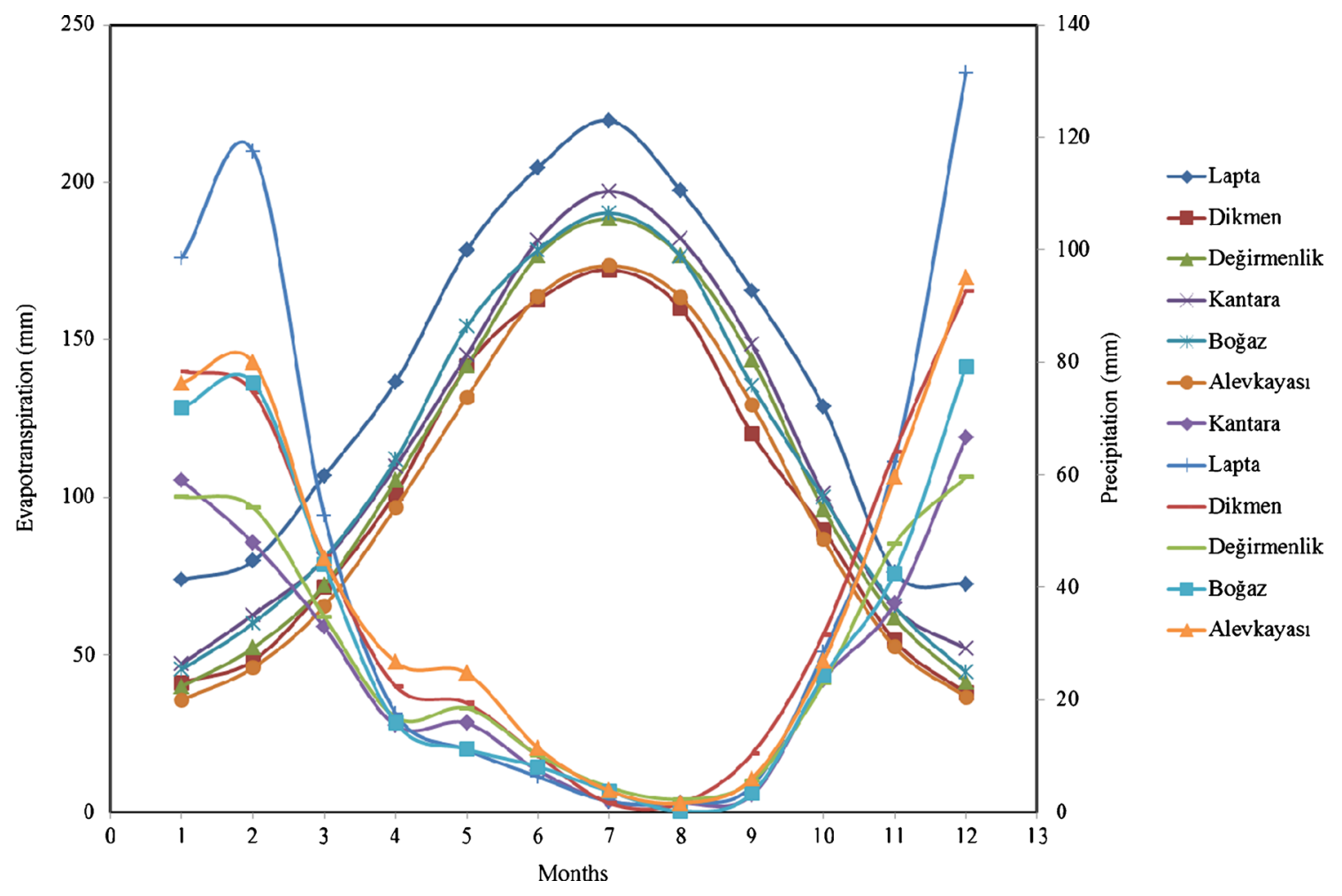

Figure 4. 10 year average monthly evapotranspiration and precipitation for different regions in Kyrenia Range. 
term average infiltration as $167 \mathrm{~mm}$. These high infiltration rates can be expected since it was related to the major and minor spring flow discharges and higher precipitation rates. Based on the above definitions, recharge for each of the subaquifers, was estimated by taking the regional monthly

Table 2. Detailed tabular analyses of each subaquifer.

\begin{tabular}{|c|c|c|c|c|c|}
\hline \multirow{2}{*}{ Region name } & \multicolumn{3}{|c|}{ Month } & \multirow[b]{2}{*}{1} & \multirow[b]{2}{*}{2} \\
\hline & & 11 & 12 & & \\
\hline \multicolumn{6}{|l|}{ Subaquifer 1 (Karşıyaka) } \\
\hline No. of wells & 3 & & & & \\
\hline Pumping rate $\left(\times 10^{6} \mathrm{~m}^{3} /\right.$ year $)$ & 0.613 & & & & \\
\hline Precipitation (mm/month) & & 62.2 & 131.4 & 98.5 & 117.5 \\
\hline Evapotranspiration (mm/month) & & 76.2 & 72.5 & 73.8 & 79.8 \\
\hline Infiltration (mm/month) & & 0 & 58.9 & 24.7 & 37.7 \\
\hline Surface area $\left(\times 10^{6} \mathrm{~m}^{2}\right)$ & 0.097 & & & & \\
\hline Volume $\left(\times 10^{6} \mathrm{~m}^{3}\right)$ & 7.91 & & & & \\
\hline \multicolumn{6}{|l|}{ Subaquifer 2 (Lapta) } \\
\hline No. of wells & 3 & & & & \\
\hline Pumping rate $\left(\times 10^{6} \mathrm{~m}^{3} /\right.$ year $)$ & 0.622 & & & & \\
\hline Precipitation (mm/month) & & 62.2 & 131.4 & 98.5 & 117.5 \\
\hline Evapotranspiration (mm/month) & & 76.2 & 72.5 & 73.8 & 79.8 \\
\hline Infiltration (mm/month) & & 0 & 58.9 & 24.7 & 37.7 \\
\hline Surface area $\left(\times 10^{6} \mathrm{~m}^{2}\right)$ & 0.18 & & & & \\
\hline Volume $\left(\times 10^{6} \mathrm{~m}^{3}\right)$ & 15.37 & & & & \\
\hline \multicolumn{6}{|l|}{ Subaquifer 3 (Alsancak) } \\
\hline No. of wells & 2 & & & & \\
\hline Pumping rate $\left(\times 10^{6} \mathrm{~m}^{3} /\right.$ year $)$ & 0.657 & & & & \\
\hline Precipitation (mm/month) & & 62.2 & 131.4 & 98.5 & 117.5 \\
\hline Evapotranspiration (mm/month) & & 76.2 & 72.5 & 73.8 & 79.8 \\
\hline Infiltration (mm/month) & & 0 & 58.9 & 24.7 & 37.7 \\
\hline Surface area $\left(\times 10^{6} \mathrm{~m}^{2}\right)$ & 0.22 & & & & \\
\hline Volume $\left(\times 10^{6} \mathrm{~m}^{3}\right)$ & 18.33 & & & & \\
\hline \multicolumn{6}{|l|}{ Subaquifer 4 (Karaman) } \\
\hline No. of wells & 4 & & & & \\
\hline Pumping rate $\left(\times 10^{6} \mathrm{~m}^{3} /\right.$ year $)$ & 1.095 & & & & \\
\hline Precipitation (mm/month) & & 42.5 & 79.2 & 71.9 & 76.3 \\
\hline Evapotranspiration (mm/month) & & 67.5 & 57.4 & 56.4 & 61.8 \\
\hline Infiltration (mm/month) & & 0 & 21.8 & 15.5 & 14.5 \\
\hline Surface area $\left(\times 10^{6} \mathrm{~m}^{2}\right)$ & 0.69 & & & & \\
\hline Volume $\left(\times 10^{6} \mathrm{~m}^{3}\right)$ & 13.38 & & & & \\
\hline \multicolumn{6}{|l|}{ Subaquifer 5 (Dikmen) } \\
\hline No. of wells & 3 & & & & \\
\hline Pumping rate $\left(\times 10^{6} \mathrm{~m}^{3} /\right.$ year $)$ & 0.630 & & & & \\
\hline Precipitation (mm/month) & & 42.5 & 79.2 & 71.9 & 76.3 \\
\hline Evapotranspiration (mm/month) & & 54.6 & 37.8 & 41.2 & 48.1 \\
\hline Infiltration (mm/month) & & 0 & 41.4 & 30.7 & 28.1 \\
\hline Surface area $\left(\times 10^{6} \mathrm{~m}^{2}\right)$ & 0.49 & & & & \\
\hline Volume $\left(\times 10^{6} \mathrm{~m}^{3}\right)$ & 12.21 & & & & \\
\hline \multicolumn{6}{|l|}{ Subaquifer 6 (Çatalköy) } \\
\hline No. of wells & 7 & & & & \\
\hline Pumping rate $\left(\times 10^{6} \mathrm{~m}^{3} /\right.$ year $)$ & 1.787 & & & & \\
\hline Precipitation (mm/month) & & 59.6 & 95.1 & 76.3 & 80 \\
\hline Evapotranspiration (mm/month) & & 61.8 & 42.8 & 41.2 & 48.7 \\
\hline Infiltration (mm/month) & & 0 & 52.3 & 35.1 & 31.3 \\
\hline Surface area $\left(\times 10^{6} \mathrm{~m}^{2}\right)$ & 2.46 & & & & \\
\hline Volume $\left(\times 10^{6} \mathrm{~m}^{3}\right)$ & 61.6 & & & & \\
\hline
\end{tabular}


Table 2. (Continued).

\begin{tabular}{|c|c|c|c|c|c|}
\hline \multirow[b]{2}{*}{ Region name } & \multicolumn{3}{|c|}{ Month } & \multirow[b]{2}{*}{1} & \multirow[b]{2}{*}{2} \\
\hline & & 11 & 12 & & \\
\hline \multicolumn{6}{|l|}{ Subaquifer 7 (Değirmenlik) } \\
\hline No. of wells & 5 & & & & \\
\hline Pumping rate $\left(\times 10^{6} \mathrm{~m}^{3} /\right.$ year $)$ & 2.33 & & & & \\
\hline Precipitation (mm/month) & & 47.7 & 59.6 & 56.1 & 54.2 \\
\hline Evapotranspiration (mm/month) & & 61.8 & 42.8 & 41.2 & 48.7 \\
\hline Infiltration (mm/month) & & 0 & 16.8 & 14.9 & 5.5 \\
\hline Surface area $\left(\times 10^{6} \mathrm{~m}^{2}\right)$ & 2.09 & & & & \\
\hline Volume $\left(\times 10^{6} \mathrm{~m}^{3}\right)$ & 51.44 & & & & \\
\hline \multicolumn{6}{|l|}{ Subaquifer 8 (Alevkayası) } \\
\hline No. of wells & 2 & & & & \\
\hline Pumping rate $\left(\times 10^{6} \mathrm{~m}^{3} /\right.$ year $)$ & 0.28 & & & & \\
\hline Precipitation (mm/month) & & 59.6 & 95.1 & 76.3 & 80.0 \\
\hline Evapotranspiration (mm/month) & & 52.5 & 37.8 & 36.9 & 42.8 \\
\hline Infiltration (mm/month) & & 7.10 & 57.3 & 39.4 & 37.2 \\
\hline Surface area $\left(\times 10^{6} \mathrm{~m}^{2}\right)$ & 0.21 & & & & \\
\hline Volume $\left(\times 10^{6} \mathrm{~m}^{3}\right)$ & 4.24 & & & & \\
\hline \multicolumn{6}{|l|}{ Subaquifer 9 (Tirmen) } \\
\hline No. of wells & 3 & & & & \\
\hline Pumping rate $\left(\times 10^{6} \mathrm{~m}^{3} /\right.$ year $)$ & 3.74 & & & & \\
\hline Precipitation (mm/month) & & 64.1 & 92.6 & 78.4 & 74.6 \\
\hline Evapotranspiration (mm/month) & & 65.4 & 53.6 & 48.7 & 58.5 \\
\hline Infiltration (mm/month) & & 0 & 39.0 & 29.7 & 16.1 \\
\hline Surface area $\left(\times 10^{6} \mathrm{~m}^{2}\right)$ & 0.23 & & & & \\
\hline Volume $\left(\times 10^{6} \mathrm{~m}^{3}\right)$ & 7.87 & & & & \\
\hline \multicolumn{6}{|l|}{ Subaquifer 10 (Kantara) } \\
\hline No. of wells & 3 & & & & \\
\hline Pumping rate $\left(\times 10^{6} \mathrm{~m}^{3} /\right.$ year $)$ & 0.403 & & & & \\
\hline Precipitation (mm/month) & & 66.3 & 118.9 & 105.4 & 85.5 \\
\hline Evapotranspiration (mm/month) & & 65.1 & 53.6 & 48.6 & 58.5 \\
\hline Infiltration (mm/month) & & 1.20 & 65.3 & 56.8 & 27.0 \\
\hline Surface area $\left(\times 10^{6} \mathrm{~m}^{2}\right)$ & 0.25 & & & & \\
\hline Volume $\left(\times 10^{6} \mathrm{~m}^{3}\right)$ & 19.66 & & & & \\
\hline \multicolumn{6}{|l|}{ Subaquifer 11 (Boğaz) } \\
\hline No. of wells & 3 & & & & \\
\hline Pumping rate $\left(\times 10^{6} \mathrm{~m}^{3} /\right.$ year $)$ & 1.183 & & & & \\
\hline Precipitation (mm/month) & & 42.5 & 79.2 & 71.9 & 76.3 \\
\hline Evapotranspiration (mm/month) & & 65.4 & 45.8 & 46.8 & 56 \\
\hline Infiltration (mm/month) & & 0 & 33.4 & 25.1 & 20.3 \\
\hline Surface area $\left(\times 10^{6} \mathrm{~m}^{2}\right)$ & 0.69 & & & & \\
\hline Volume $\left(\times 10^{6} \mathrm{~m}^{3}\right)$ & 2.19 & & & & \\
\hline
\end{tabular}

differences between rainfall and evapotranspiration. The mean monthly recharge estimated for the last 10 years ranged from 51.8 to $150.3 \mathrm{~mm}$, representing $3.5-16.5 \%$ of the annual rainfall for each region. The largest and smallest recharge values were estimated for Kantara and Değirmenlik, respectively (table 2). Recharge within the range differed spatially due to northern and southern faces of the ranges and also the land use and soil characteristics of different locations. The details of the monthly recharges of each subaquifer region are given in table 2 .

\subsection{Abstraction rates and head changes}

Attention by the authorities has been given lately to the question of the amount of storage available in the subaquifers, which is the storage within the limestone formations. Due to the depletion of water levels, boreholes have been drilled considerably at 
greater depths than in earlier years. Several are around $305 \mathrm{~m}$ in depth, and one exceeds $455 \mathrm{~m}$.

Depending on their size, spatial location, groundwater level and the rate of abstraction, well heads vary from each subaquifer. These head differences support the assumptions of Dixey (1972) that the Kyrenia Range consists of individual, independent limestone compartments separated from one another by faults and other structural features.

The aquifer heads tend to fluctuate in response to the recharging and withdrawal rates. Accordingly, the head changes with respect to time at each subaquifer are figured out. Information about the daily duration and rate of pumping of each well were gathered in order to calculate the annual water abstraction from each well.

Almost 62 wells have been monitored since 1998 . Among these wells, 12 of them are used to abstract groundwater for domestic purposes serving 45,000 residents; whereas agricultural consumption is not possible due to high cost of borehole drilling and high electricity costs for agricultural purposes. 22 of these wells are abandoned during the last 10 years since the wells have dried due to overpumping. The rate of pumping from each well ranges between 15 and $35 \mathrm{~m}^{3} / \mathrm{hr}$, where each one pumps 24 hours a day.

The efficiency of the water budget of the aquifer lies in the actual behaviour of the water table of each subaquifer. On an average, it was important to observe whether the water table remained steady or was falling. In principle, this determination would be simple, in that it would require the recording of the movements of the water table in a wide monitoring process. The observations have shown that the water table movements were not only variable but erratic, depending on pumping rates, rainfall, and infiltration in short and medium term. Monitored water level records show that annual local variation of the water level varies between 2 and 15 m, e.g., Kantara subaquifer. Figure 5 demonstrates the head changes in Değirmenlik subaquifer.

Although the water level in wells tends to rise during the rainy season (mid-November to midMarch), recharging of the aquifer is not successfully managed for balancing the water consumption of the subaquifers. Previously, discharge from the subaquifers was naturally, via the springs.

\subsection{Subaquifer capacity measurements}

As a result of data compilation, a total abstraction from the wells which are spatially distributed on Kyrenia Range subaquifers, is $1523 \mathrm{~m}^{3} / \mathrm{hr}$ resulting in 13.34 MCM water consumption per year. Intense pumping decreses the water levels drying out the springs of the region. Small spring discharges can be observed at Lapta region discharging 0.8 cubic meters per hour. Consequently, it is observed that the spring flows are not worth considering as a means of water consumption from the existing aquifer systems.

According to table 2, total pumping rate from the aquifer is 13.34 million cubic meters per year.

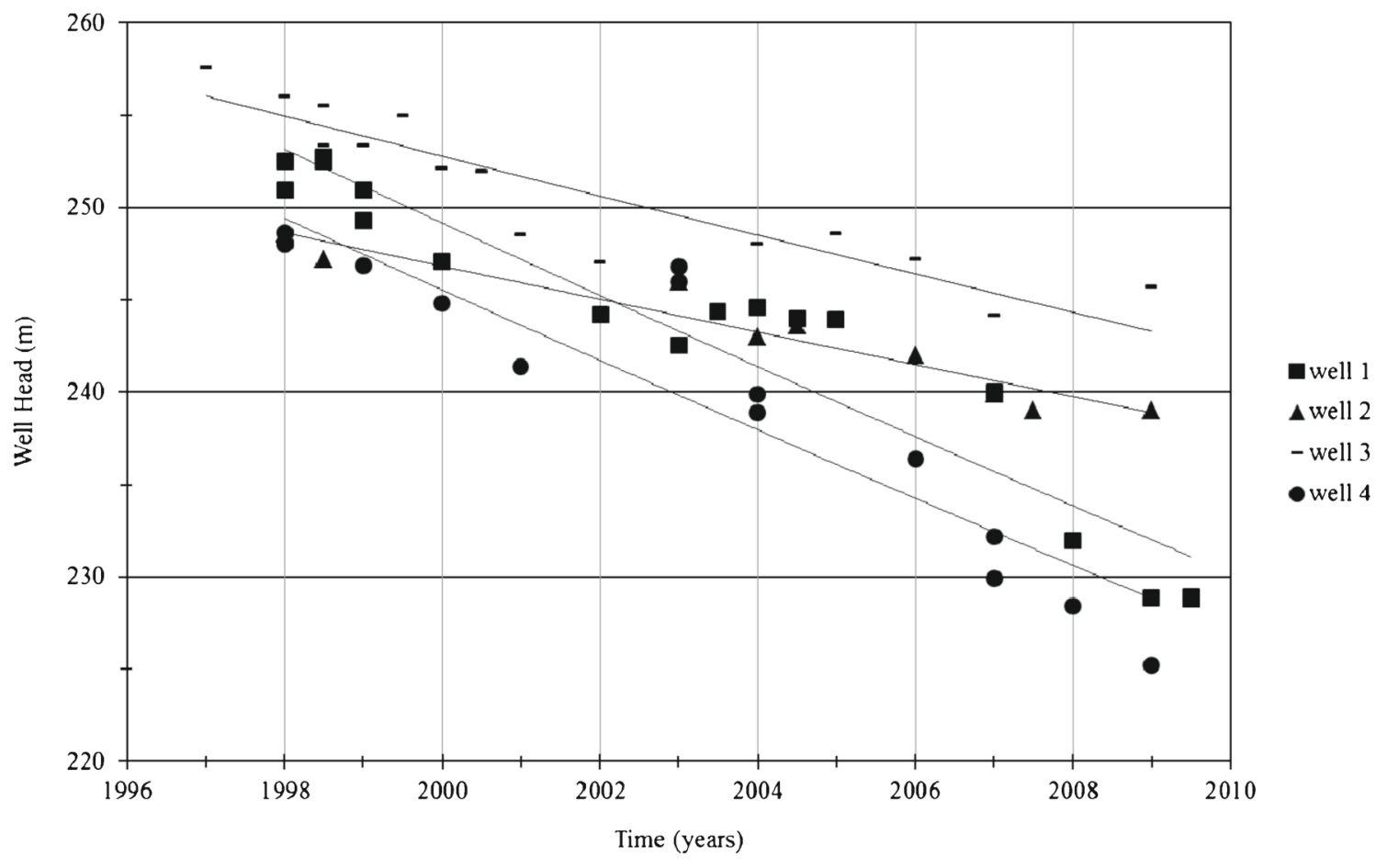

Figure 5. The changes in head of wells at Değirmenlik subaquifer. 
The water budget calculations based on hydrologic assumptions and field analysis presented the total volume of water stored in Kyrenia Range aquifers. The summary of the results are shown in table 2, in which the total water stored in the aquifer sums up to $214.2 \mathrm{MCM}$.

It is well known that the best means of control of the aquifer would be to increase the water table levels up to such a degree that the springs would virtually start to flow again, so that the winter spring flows will be directed for use also in agricultural requirements. For this purpose, there would be a need to stop pumping for domestic purposes for several years. Once the control of the springs has been achieved, then the problem would be to maintain the balance between recharge and discharge. Regular spring flows can be achieved by keeping the yearly discharges equivalent to only spring flows and abandoning the well discharges.

Already ongoing pipeline project that will deliver the water from southern part of Turkey to northern part of Cyprus is waiting for the completion of 67 $\mathrm{km}$ Mediterranean Sea cross works. The pipe will deliver $75 \mathrm{MCM}$ of water per year, which would easily meet domestic water demands of the northern part of Cyprus. Any success in this project would not only solve most of the water problems of the northern part of Cyprus, but also add an alternative water resources management method, especially for those islands and countries that have faced successive droughts for the last decade.

\section{Conclusions}

Groundwater resources have been evaluated for the Kyrenia Range subaquifers that are subjected to numerous pressures by ongoing intensive domestic water demands due to successive droughts at Cyprus. Long term monitoring programs have been performed in this region to evaluate the physical behaviour of the subaquifers and estimate the water budget of the available stored water. The detailed information about the wells was collected during well survey studies. The annual groundwater abstractions for domestic purposes from each aquifer have been estimated and it has been discovered that it sums up to 13.34 MCM per year. Evapotranspiration estimates were carried out together with precipitation data, which was gathered from meteorological stations close to the study area. Recharge of each subaquifer has been estimated on the basis of the difference between the monthly evapotranspiration and precipitation values, in which the drainage area of the basin are expected to have negligible surface runoff. The resultant annual groundwater recharge due to precipitation has been estimated as $1126 \mathrm{~mm}$. It is analyzed that on the basis of the model developed in this study, the total amount of available storage is about $214 \mathrm{MCM}$ per $200 \mathrm{~m}$ of depth. The results have been obtained from the studies on available wells, since the environmental factors limited the application of geophysical methods. The investigation into the water resources of the Kyrenia Range show that the only alternative for the rehabilitation of the subaquifers is abandoning the domestic water supply wells and replacing them by an alternative water resource. This can help to increase the water levels and to identify opportunities for the occurrences of spring flows in the future.

\section{Acknowledgements}

The discussions and findings of this paper are based in part on data generated by a monitoring study of the Kyrenia Range aquifers conducted by the State Water Works Department. The authors would like to acknowledge this important contribution and thanks to Mustafa Sidal and Temel Rizza for their contributions and comments.

\section{References}

Burdon D J 1952 The underground water resources of Cyprus; Research Report, Nicosia, Water Supply and Irrigation Department, Cyprus.

Dixey F 1972 The geology and hydrogeology of the Kyrenia Range; Draft Research Report, Ministry of Overseas Development, London, UK.

Dreghorn W 1978 Landforms in the Girne Range, northern Cyprus; Research Report, 172 Ankara, The Mineral Research and Exploration Institute of Turkey.

Ducloz C 1965 The geology and water resources of the Kyrenia Range; Research Report, United Nations Groundwater and Mineral Resources Survey, Cyprus.

Ducloz C 1972 Geological map of the central Kyrenia Range; In: The geology of the Bellapais-Kythrea area of the central Kyrenia Range, Bulletin no. 9, Geological Survey Department, Cyprus.

Endreny T and Gokcekus H 2008 Ancient eco-technology of qanats for engineering a sustainable water supply in the Mediterranean island of Cyprus; Environ. Geol. 57(2) 249-257.

Erduran B, Gökmenoğlu O and Keskin E 2004 Hydrogeology of the Besparmak Mountains karstic aquifers (in Turkish); Geol. Eng. 28(1) 11-25.

Flint A L, Hevesi J A and Flint L E 1996 Conceptual and numerical model of infiltration for the Yucca Mountain Area; Research Report, Nevada, US Geological Survey, US Geological Survey.

Gökmenoğlu O, Erduran B, Özgür C and Tamgaç Ö F 2004 The hydrogeological report on northern part of Cyprus; Research Report (in Turkish), Ankara, The Mineral Research and Exploration Institute of Turkey.

Harrison R et al. 2008 Bedrock geologic map of the greater Lefkosia area, Cyprus; Research Report, US Geological Survey Scientific Investigations. 
Kluyver H M 1967 Progress report on the geological mapping of the central eastern Kyrenia Range, Cyprus; Research Report, UN Survey, Cyprus.

Liu H H 2011 Impact of climate change on groundwater recharge in dry areas: An ecohydrology approach; J. Hydrol. 407(1-4) 175-183.

Mixius F K and Kreysing R 1965 Hydrogeological investigations and groundwater development in the Kyrenia Range of Cyprus; Research Report, Hannover, Germany.

Obuobie E, Diekkrueger B, Agyekum W and Agodzo S 2012 Groundwater level monitoring and recharge estimation in the White Volta River basin of Ghana; J. Afr. Earth Sci. 71-72(9) 80-86.

Pantazis T M 1978 Cyprus evaporites; Med. Geol. 42(2) 1185-1194.

Türker U, Alsalabi B S and Rizza T 2013 Water table fluctuation analyses and associated empirical approach to predict spatial distribution of water table at Yeşilköy/ Agios Andronikos aquifer; Environ. Earth Sci. 69(1) 63-75.

UNDP 1970 Survey of groundwater and mineral resources; Research Report, Cyprus UN, New York.

MS received 18 June 2014; revised 7 September 2014; accepted 3 November 2014 